Compare with this the extent of knowledge expected in other subjects. French and German, for example, together form one subject: to succeed, the candidate must be proficient in dictation in each language ; translation from unseen authors; the grammar, history, and etymology of the languages; translation from English into French and German, besides translation from books appointed. For the last examination, books which might be chosen were-in French, Pascal's "Provincial Letters;" in German, Goethe's "Faust" and "Italiänische Reise."

The relative value attached to different branches of science is also worthy of remark. Chemistry, for example, is supposed to be so far inferior to Botany as an educational study, that the slight subject of $F^{2}$ eat is added as a make-weight.

It is really hard to determine whether the compilers of these Regulations (the head-masters of one or two of our most important schools being amongst them, if report errs not) have acted simply in ignorance of what physical science in a school ought to be, or whether this is an inge. nious device to strangle science as a school study, and to get rid of the obnoxious interloper by driving the weak and idle to it, and thus giving it a bad name as "the refuge of fools."

N. Marshall Watts

\section{PROF. MAX MÜLLER}

$7 \mathrm{~T}$ was decided at a Convocation held at Oxford on 1 Tuesday that an inducement should be offered to Prof. Max Müller to continue to honour Oxford by remaining connected with that University. It would certainly have been a disgrace had no effort been made to retain the services of so eminent a scholar, which other countries are eagerly anxious to obtain. The proposal made by the Dean of Christ Church, which was carried by a large majority, was to relieve Prof. Müller of the obligation to lecture, and to provide for the appointment of a deputy, who should receive one-half of the salary of the present Professor. This scheme is confessedly somewhat of a makeshift ; time was of importance, and the proper course, by statute, because lengthy, was not available. Vienna had offered the Professor a Chair of Sanskrit and provision for the publication of his books; and to this offer an immediate answer was necessary. The present, the Dean wished it to be understood, was a provisional arrangement in view of impending changes. The Dean was authorised to state that the Government "Universities" Bill would constitute an Executive Commission, with powers to receive schemes from Colleges, and to base upon them the new University and Collegiate organisation. He pledged himself there should be an opportunity given for considering in constitutional form the permanent arrangement of the matter at present in hand. He defended the decree from the charge of robbing Comparative Philology, for Sanskrit studies were an essential part of it, and the arrangement would give an admirable opportunity for some young man to make out his claim to the Professorship. He could have wished the arrangement had been more liberal, but, in fact, the University had come to the end of its tether. The Dean then dwelt on the high value of the Professor's services. He told how Mr. Max Muiller had "audaciously" projected, when but a youth and a pupil of Burnouf, an edition of the Rigveda. For this he was forced to come to England, for which purpose he raised funds by translations, \&c. Bunsen, on whom he called without introduction, had forwarded him to Prof. Wilson, and the India House, with sagacious liberality, took him up. Dean Gaisford had bidden men read Homer, with some ancient commentator, as the key to Greek literature. If these had been only accessible in manuscript, involving the reading, indexing, and perpetual annotation of infinite other MSS, who would bave un dertaken the task? And this was what Max Müller had done. Dean Liddell knew not whether to admire and wonder at most-his ardour in commencing, his perseverance in continuing, or his genius in the execution of his work. With regard to a recent statement as to Prof, Muiller's future work, the Dean stated the fact to be that the University had accepted the offer of publishing a choice selection of translations from Sacred Books-at the utmost, twenty-four volumes. But this, it was obvious, was sufficient to prevent the Professor from enjoying the position of a sinecurist. The Dean concluded by enumerating a list of the Professor's distinctions, and urged the University to keep him if it could, how it could, while it could.

We must say that most of those who spoke in the discussion which followed missed the freal point at issue. Prof. Max Miller has already rendered such important services to Oxford, to England, and to Science, and proved himself so competent to continue these services, that there should have been no hesitation whatever about endowing him sufficiently to enable him to continue his valuable researches unhampered. But we must be thankful for small mercies at present, hoping from the hint dropped by the Dean that better things are in store.

\section{PROF. NORDENSKFÖOD ON THE FENISEI}

I HAVE before mentioned the great abundance of extrarordi. narily delicate varieties of fish which Jenisei yields, and that during our river joutney we made as complete a collection of them as possible. The steamer's tedious vnyage was, besides, employed by me in collecting statenents regarding the names of the most important varieties, the price paid for them on the steamer, and their size.

\begin{tabular}{|c|c|c|c|c|c|c|c|c|c|c|}
\hline \multirow{8}{*}{$\begin{array}{l}\text { Njelma } \\
\text { Tschir } \\
\text { Omul } \\
\text { Muksum } \\
\text { Salmon } \\
\text { Sterlet } \\
\text { Sturgeon } \\
\text { Silj }\end{array}$} & \multirow{2}{*}{\multicolumn{3}{|c|}{$\begin{array}{l}\text { Common } \\
\text { weiglit. } \\
\text { I3 Ib. }\end{array}$}} & \multirow{2}{*}{\multicolumn{3}{|c|}{$\begin{array}{l}\text { Greatest } \\
\text { weight. }\end{array}$}} & \multicolumn{4}{|c|}{ Price. } \\
\hline & & & & & & & $\cdots$ & 801 & kop. & per po \\
\hline & $\ldots$ & 6 & ", & $\ldots$ & 25 & $"$ & $\ldots$ & IO & $"$ & each. \\
\hline & $\ldots$ & $I_{2}^{\frac{1}{2}}$ & ", & $\ldots$ & 3 & 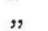 & $\ldots$ & 2 & " & " \\
\hline & $\ldots$ & 4 & " & $\ldots$ & 12 & 3 & $\ldots$ & 9 & $"$ & $"$ \\
\hline & $\ldots$ & 16 & $"$ & $\ldots$ & 80 & " & $\cdots$ & - & & \\
\hline & $\cdots$ & 3 & ", & $\cdots$ & 30 & $"$, & $\ldots$ & I50 ] & kop. & per poo \\
\hline & $\begin{array}{l}\cdots \\
\ldots\end{array}$ & & 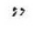 & $\begin{array}{l}\cdots \\
\cdots\end{array}$ & 200 & $")$ & $\ldots$ & 40 & & \\
\hline & $\cdots$ & & & & & & & 40 & $"$ & $s$ \\
\hline
\end{tabular}

The trade, however, is carried on here in this way, that the goods to be purchased are valued in coin, but payment is made in goods at the merchant's valuation, on which accoun the true price is perhaps considerably below that which is here stated.

After the numerous crew on the Alexander and the "lodjors" had attended with great devoutiness a festival service in the church of the monastery and a neighbouring chapel where the holy founder's dust and work-harness are preserved, after we had seen several of the remarkable things belonging to the monastery, and among them an exceedingly well-preservect Scla. vonic Bible from the sixteenth century, and after I had paid a visit, along with the captain, to an aged cripple who in his youth had made a pilgrimage to Jerusalem, we steamed on. Our progress, as was commonly the case, was slow, in consequence of the strong current and the frequent stoppages, which of course we turned to account by making excursions to examine the natural history of the region, by conversing with the inhabitants, \&c. The latter consist partly of Russians who have settled there, partly of natives, "Asiatics," who frequent the rivers during summer, partly on their orn account, partly as employed by Russians. In such circumstances their dwellings consist of tents of quite the same form as the Lapp "kota." The Samoyede tent is commonly covered with reindeer skins, the Ostiak tent with birch bark. A number of dogs are always found in the neighbourhood of the tent, which during winter are used for general draught purposes, and in summer for towing up boats against the current-a means of transport on water which greatly surprised our seal-fishers. For this purpose a sufficient number of dogs are harnessed to a long line, one end of which is fastened to the stem of the boat. The dogs then go forward upon the level bank, where in this way

I Continued from p. 277 .

2 Njelma, Tschir, Omul, and Muksum are varieties of the Gwyniad. Silj is the fry, or young, of the same fish. 
true dog-tracks are formed, and the boat, which requires only a moderate depth of water, is kept afloat at a sufficient distance from the bank by the rudder, which is managed by a person sitting in the stern of the boat. The boats are often hollowed out of a single tree stem, and may be notwithstanding, thanks to the dimensions the trees attain in these regions, of very beautiful form and very large. The dogs have a strong resemblance to the Eskimo dogs in Greenland, which are also employed as draught animals, which may perhaps be considered a proof that the same climatic circumstances and a similar method of employing a species of animals create like races. Most of the natives who come into intimate contact with the Russians at the present time, we are informed, profess Christianity. That many heathen customs still, however, cleave to them is shown by the following incident. At a "simovie" where we landed for some hours on Sept. r6, we as usual came upon a burying-place in the wood near the dwelling-houses. The corpses were laid in large coffins above ground, with a cross in nearly every case raised over them. At one of the graves there was a consecrated picture fixed to the cross, which must be considered an additional proof that a Christian reposed in the coffin. Notwithstanding this, several garments, which had belonged to the deceased, were found hanging on a bush near the grave, together with a bundle containing food, principally dried fish. At the graves of the richer natives we are informed that the survivors place, together with food, some rouble notes, in order that the departed may not be altogether destitute of ready money on his entrance into the other world. But that fine clothes are not considered any special recommendation with St. Peter was evidenced by the exceedingly shabby, tattered, and patched condition of the garments hung up at the grave in question.

Hitherto we had during our journey from Dudino up the Jenisei for the most part very fine, often warm, autumn weather. The first frost occurred south of Saostrovskoi on the night before Sept. 20, and from that date the temperature of the nights was generally under the freezing point. The days, however, continued to be warm and fine. The fall of rain was slight.

On the 2oth we anchored at the mouth of one of the largest tributaries which fall into Jenisei from the east, viz., Podkammennaja Tunguska. Immediately below a welcome opportunity offered of taking soundings right across the river, which is here over a kilometre broad. A little distance from the western bank the lead showed four fathoms, afterwards the depth again diminished to $2 \frac{1}{2}$ fathoms, but afterwards increased anew to seven fathoms. At a number of other places also soundings were taken, which are believed to confirm the statement of the pilots that the depth of the river as far up as Jeniseisk is sufficient even for large vessels. However, in order to establish this with complete certainty, and to discover the most convenient channel for navigation, much more complete hydrographical surveys are required than those which we had an opportunity of making in passing.

As I have already mentioned, productive potato land and. cabbage plots are to be found at the Skeptists' Colony, north of the Arctic circle, and the farther south we came, the more such patches of cultivation increased in size. No proper cultivation of grain is met with until we reach Sykobatka, situated in lat. $60^{\circ}$, but in the future it is quite certain that when the woots and morasses are diminished, a profitable agriculture may be carried on much farther north. Already from this point to the southern boundary of Siberia, or more correctly to the steppe lands of Central Asia, we have at most places more than roo $S$ wedish miles (r,000 kilometres), and if we consider that a belt of land of this breadth, for the most part covered with excellent, easily cultivated soil, extends right across the whole of Asia from Ural to the Pacific Ocean, we may form an idea of the immeasur. able field of conquest for the plough of the cultivator which these regions offer, and the future which some time must open up for it.

Immediately south of Sykobatka we passed the church village Nasimowskoi, and a deserted gold-washer's "residence" lying right opposite, named after the first conqueror of Siberia, Jermakova. The "residence" originated in the discovery of beds of sand rich in gold in the pretty extensive territory of a tributary of Jenisei on the east of that river, which before the Californian discovery was renowned as the richest gold district of the globe. In a short time many colossal fortunes were made here, and the stories of the hundreds of pouds which one or another yearly washed, and the reckless, riotous mode of life of those whom fortune allowed to win the great prizes in the gold-washing lottery, still forms a favourite subject of conversation in the region. Heightened rates of labour and diminished supplies of the noble metal have, however, of late, led to the abandonment of a number of the washings which formerly were most profitable, and the others scarce pay for the working. Many of the gold washers who were formerly rich, have, in the attempt to increase their wealth, been ruined, and disappeared; and others who succeeded in retaining their poud of gold-that is the mintunit that the gold washers prefer to employ in conversationhave removed to Paris, Petersburg, Moscow, Omsk, Krasnö. jarsk, \&c. All the "residences" are therefore now deserted, and form on the eastern bank of the river a row of half-decayed wooden ruins surrounded by young trees, after the disappearance of which in a short time only the tradition of the former era of prosperity will be found remaining. In one respect, however, these gold-washers have exercised a lasting influence on the future of the country; for it was through them that the first pioneers were spread in this desolate land, the first seed sown of the cultivation of the region.

At many places along the river there is to be seen besides another peculiar memorial chiefly from the time when thousands of labourers were collected at the gold-washings, viz., colossal flat-hottomed boxes formed of logs, which are here called "barks," which lie drawn up on the banks, more or less decayed. They were used for the transport of the necessaries of life on the river from Southern Siberia, and an idea may be formed of the calm flow of the Siberian rivers and their suitableness for water communication, from the fact that in this way goods were transported as far as the most northerly "simovies" on the Jenisei, on the main river, from regions situated south of Minusinsk, near the Chinese frontier and along its tributary the Angara from Lake Baikal; in fact, still farther, for even the river Selenga, which falls into Lake Baikal from the south, is navigable for a good part of its course. In order, however, to sail up these rivers from Jeniseisk there are required, as I have stated before, some operations for clearing the channel, but they are inconsiderable in comparison with the importance of the object. "Barks" of average size, built for the carriage of grain from Minusiusk, cost 300 roubles, load up to 130 tons, and are managed during the voyage down the river by fifteen men. After reaching their destination they are sold, in case a buyer can be found, for a few roubles. Notwithstanding their awkward shape they are well adapted for the river communication in question, and they would be still more so if during the down voyage of a considerable train formed of twenty or thirty of such craft, a sinall steam-tug coulc be had like those that are employed in the Archipelago of Stockholm. In this way the crew on each "bark" might be reduced to one-third; and the freight, which is already low, be farther reduced.

Since Sept. 20 night frosts had often occurred, which naturally considerably diminished the results of our excursions at the steamer's stopping places. We became therefore more impatient to reach our nearest destination. The strong current and the frequent stoppages delayed our journey, so that it was not until Sept. 30 that we could anchor at the town Jeniseisk: Here we stayed some days for the purpose of getting news from Europc, examining the fine collections made in several branches of natural history by Herr M. Marks, an exile, and settling our affairs; in connection with which I ought specially to mention that the owner of the Alexander, Herr Balangin, declined to receive any payment for our long voyage in the steamer, on which $I$ made over instead, as a memorial to him and the excellent master of the steamer, Herr Jarmenieff, the Nordland boat, in which we began our river journey, and which had afterwards been brought hither in tow.

We then proceeded on our return journey by land through Krosnojarsk, Tomsk, Omsk, Tjumen, Ekaterineburg, Tagilsk, Perm, Kasan, Nischni-Novgorod, Moscow, Petersburg, and Helsinfors to Abo, and thence by steamer to Stockholm.

With the exception of some short stoppages in the large towns we travelled day and night, and a sketch of this latter part of our journey would therefore be occupied principally with the agreeable and friendly reception which we uniformly met with, and the interest which was universally felt in our polar jnurney. The correspondence which has appeared on this subject in the newspapers may perhaps free me from the obligation of saying more on this subject.

Before I finish this letter I ought finally to mention that the large collections in natural history made by the expedition both in Novaya Zemlya and the Kara Sea, and during our river journey on Jenisei, all, with the exception of a large collection of fich from Sibcria sent by caravan, have come to hand in good 
condition. For the examination and description of these collections $I$ wish to employ the younger scientific men of eminence in our country, and as the most of them cannot without too great a sacrifice undertake year-long labours more or less foreign to their proper employment, I have made an application to the Government for a grant of 10,000 crowns (about $550 \%$.) to defray the expense of working up the collections. If this application be granted, and the collections of the expedition of 1875 thus become not a dead museum-material, but fructify for the purposes of science, I hope that the sea visited by the expedition, for merly almost unknown, will soon be reckoned among those of our globe which are well known in respect of their natural history.

Part of these scientific researches besides concern purely practical questions, and I shall therefore, as they are concluded, give you a short account of them.

\section{A. E. NORDENSKJöLD}

\section{ON THE SPECTRUM OF NITROGEN AND THAT OF ALKALINE METALS IN GEISS. LER TUBES, BY M. SALET}

$\mathrm{N}_{1} 872 \mathrm{Mr}$. Schuster published the important statement that " nitrogen, heated in a Geissler tube with metallic sodium, ceased to give the characteristic channelled spectrum." He de. scribed the bright lines he got in this case, and attributed them to pure nitrogen, considering the band spectrum to be that of an oxide of nitrogen, a compound destroyed by the allsaline metal. These conclusions were afterwards disputed, for, in repetition of the experiments, the channelled spectra were seen to disappear after action of the sodium, but they were replaced by various spectra, none of which belonged to nitrogen; so that, after its purification, this gas could not be detected by prismatic analysis. The chemical compound really formed by the action of oxygen on nitrogen is (as IV. Salet pointed out) peroxide of nitrogen, a very stable stiostance, whose spectrum does not coincide with that, the appearance of which is to be explained.

In a recent note to the French Academy, M. Salet affirms (i) that the channelled spectrum may be produced with nitro. gen heated in contact with sodium; (2) that the disappearance of the nitrogen spectrum is due to that of the nitrogen itself, which is entirely absorbed by the sodium under the influence of the electric discharge ; (3) that the spectrum described by $\mathrm{Mr}$. Sciuster may probably be attributed to vapours of the alkaline metal.

Ile describes some of his more decisive experiments. A closed tuhe of hard glass was procured, I $2 \mathrm{~cm}$, long and $2 \mathrm{~cm}$. in diameter at one end were introduced two aluminium electrodes, about $I \mathrm{~cm}$ apart; to the other end was soldered a tubulure with an enlarged part, into which was put a small piece of sodium, then the tubulure soldered to the mercury pump. A vacuum having been made, the sodium was heated; it swelled and boiled, parting with bydrogen; the swelling at length ceased, and at a higher temperature the sodium was slowly volatilised. Then the apparatus was separated from the pump, with the blowpipe; and the bright liquid and globule of sodium was brought into the tube. After cooling, the enlarged part was separated, and the tube directly fused on to the pump. Then exhaustion was recommenced, and the sodium volatilised, care being taken that the condensation of the metallic vapour occurred oniy in the half of the tube not holding the electrodes; and nitrogen, pire and diry, was then admitted. A vacuum was produced anew three times with the nitrogen, the alkaline metal being volatiliserl each time. Lastly, the apparatus was closed, having a pressure of about $5 \mathrm{~mm}$. It was now possible to fuse the globules, unite them, and volatilise them afresh a dozen times in contact with the same mass of gas, without the appearance of the spark between the electrodes being in the least degree modified. The Holtz machine was used, or an induction coil with a Leyden jar; the interpolar space was roseate violet, and gave the channelled spectrum with the greatest distinctness. When the clisruptive spark of the Holtz machine is employed, the jet of roseate violet light giving the channelled spectrum is instantaneous, as can be shown by a simple method (which M. Salet described). By volatilisation the sodium may easily be brought to the neighbourhood of the electrode. It there appears in the form of brilliant globules of a very pure silver white; but if the tube be set in action, the portions subjected to the action of the luminous discharge are at once tarnished. The metallic surface quite disappears, and is replaced by a brownish black. At the same time one sees in the appearance of the electric jet changes produced which are caused by a greater rarefaction. If the surface of the sodium be renewed the action continues, and the spectrum of nitrogen presently quite disappears; the light is yellowish, and due, for the most part, to sodium; there are, in general, slight impurities (from the electrodes and glass), which give some strange lines.

M. Salet made a direct experiment to show this absorption of nitrogen by sodium under the influence of electricity. He made a tube like the one that has been described, but bearing a truncated barometer; and introduced nitrogen at a pressure of $27 \mathrm{~mm}$. The absorption of the gas was sufficient for one to be able to follow with the eye the ascent of the mercurial column. After a few minutes, having twice renewed the surface of the sodium, no difference could be perceived between the mercury surfaces in the two branches of the manometer.

The author also sought to characterise this absorption chemically. He broke a tube and treated separately with water a por. tion of the sodium remaining bright and a portion of the sodium altered by electricity. Into the solution he poured Nessler's test. One of the two liquids was strongly coloured yellow; it was that containing the altered sodium, the other was not altered in aspect. There was formed, then, under the influence of electricity, nitride of sodium decomposable by water with production of ammonia. This body is formed only at a temperature higher than red, like nitride of magnesium; or even is not produced directly at any degree of heat, like ammonia. M. Salet proposes to prepare and analyse it.

\section{NOTES}

WE hear with regret that the publications of the Geological Survey of the Territories by Prof. Hayden are likely to be stopped by the partisans of rigid economy in the U.S. House of Representatives. If this step be carried out it will be a serious loss to the scientific mer of Europe, as well as of America. The discoveries which have been made by the staff under Prof. Hayden's direction are of the highest value, both from a scientific and a commercial point of view, and the liberality with which they have been circulated in Europe by the American Government has earned the gratitude of all who care for the advancement of knowledge. We trust that the rumour is untrue. If it be true, we hope that a voice of remonstrance will go forth from Europe. The possibility of a political change putting an end to a great national work like that of Prof. Hayden illustrates one of the worst flaws in the American Constitution, the cancelling of all Government appointments at the election of a new president.

M. LEVERRter was not present at the Anniversary Meeting of the Astronomical Society to receive the medal which for a second time has been awarded him for his valuable Planetary Tables. Ill-health, caused by his recent great labours, was, we believe, the cause of his absence.

THE Annual Address of the President of the Geological Society will be given at the Anniversary Meeting to-morrow.

We are gratified by the statement contained in the Queen's Speech, that the Government intend to introduce, in the course of the session, measures relating to Primary Education and the Universities. An important article on the subject appeared in Monday's Daily Newes, in which the defects of the present constitution of our Universities are forcibly pointed out. It is also shown how important a bearing the composition of the Commission would have in the character of its work, and that it would be but a proper act of deference to the valuable labours of the Science Commission if the new commissioners numbered some eminent representatives of science. What the direction of the proposed University reforms is likely to be may be to sone extent gathered from the "inspired " hint dropped by the Dean of Christ Church, on Tuesday, in connection with the proposal to retain the services of Prof. Max Miiller for Oxford. The Dean was authorised to state that 